\title{
Correlation between Border Trade and Infrastructural Development: A Case Study of Indo-Myanmar Border Trade
}

\author{
Shoraisam Premananda Singh* and Mayengbam Lalit Singh**
}

\begin{abstract}
Developmental theories have two strategies: development via abundance of infrastructure and vice versa. It is theoretically favourable that infrastructure leads to development in economic sectors. However, in pragmatic terms, policies seem to go ahead of infrastructural development. This paper checks the possibility of infrastructural development which follows the implementation of border trade in landlocked region (North East Region of India).
\end{abstract}

Keywords: Look East Policy, Special Economic Zone, Indo-Myanmar trade, ChiSquared test.

\subsection{Introduction}

Theories of development mention two types of directions out which one describes infrastructural development should precede economic development; and other describes opposite to the above mentioned direction. Many studies have shown that there are bidirectional causalities between these two. However, extent of causing is empirically found more from infrastructure to trade (Mongelli, 2005; Singh, 2015). It is very important to study the developmental impact of trade on infrastructure in the landlocked region where prevailing institutions are fragile. So called "Look East Policy" in 1990s had been expected to boost backward North Eastern Region of India (NER). This region is landlocked but neighbours with many countries such as Nepal, China, Myanmar and Bangladesh. Opening border trade in this region has been debate whether it could develop these states in various dimensions of developments including infrastructure. The present paper checks how far the infrastructural development has been achieved at Moreh (border trade point in Manipur) since the introduction of border trade under Look East policy (LEP).

* M.Phil., University of Hyderabad.

**Independent Scholar (email: may.lalit@gmail.com) 
The paper employs non parametric analysis (Chi-Squared test) to draw significance of dependence between infrastructural development and trade using information from respondents which include traders, government officials in various departments and customs officials.

\subsection{Developments in Health Sector}

There have been lots of improvements in health sector since the opening border trade with Myanmar. State government has been directing health officials to improve health conditions (mainly to take care of patients). It has a sub divisional hospital and takes responsibility for health care of residents. The hospital takes care not only for local residents but also for patients from Myanmar. In normal, patients not less than thirty from Myanmar have been reported for treatment. According to these officials, number increases to thousand for treatment of seasonal diseases such as malaria, typhoid, viral fever, etc. Officials also pay special attention to these foreign patients who are very backward. Till date, parts of Myanmar which are bordering are very backward in infrastructural facilities of medicine. Their nearest destination is Manipur where they can avail themselves with proper treatment at cheapest rate. For serious treatment they come to Imphal. However, for minor treatment they visit to hospital at Moreh. Authorities of Myanmar also co-operate medical officials at Moreh in a reliable way. There is no visa restriction for such poor patients. Manipur government also arranges for visa on arrival policies for these patients. Such co-operation will benefit people living on both sides of border. According to these officials, Manipur has enough human resources which are specialising in health sector. If both government and private sectors co-operate in health sector in setting up hospitals in Manipur, the state would be a hub for medical tourism and it will boost local economy.

\subsection{Development regarding Land Customs}

According to officials at Land Customs Office, Moreh, Indian government has many taxation and customs duties which have been on the path of relaxation. At present Indian officials levy five percent value added tax on various imported items under normal trade. These normal items are characterised by necessity in day to day consumption but not food items. They have wide range of items both sides have been proposing policies of reducing tariff rates and spectrum of such items

However, for those items under the free trade the department levy zero tariffs on these goods. These items are characterised as grocery items mainly and they are in need for day to day consumption. Export and import of such items are free of duties. Both 
North East and Myanmar have similar soil fertility, vegetation and human race. Hence, food habit and culture of people are almost same. Demand structures across this region are much influenced by price variation. In brief, production of certain commodities in North East region may be hampered by less rainfall. Again supply of these commodities may not be supplemented by production in mainland India. In order to meet the demand, consumers in North East India have to import from Myanmar. This implies that the two economies are complementary to each other.

\subsection{Development in Promotion of Trade Centre}

Roles of officials at Moreh trade centre are broadly studying border trade in terms items of inclusion and holding regular meetings with submitting reports to both India and Myanmar. They review demand structures of North East India and Myanmar regularly. They supervise functioning of border trade and submit new policies. Hence their role in development of trade is intermediary officials. They regularly hold meetings with trade officials of Myanmar. Owing to their commitments, Moreh has turned into a place which can be compared to Special Economic Zone (SEZ). During pre LEP, such trade centre was not functioning. However, LEP compels to establish such institutions which give the platforms whereon negotiations have been taking place. According to these officials, they need government funding and special attention to their proposal for further development of Moreh.

\subsection{Opinions on New Policies in Relation to Trade}

This section presents the opinions on trade policies to boost trade. Figure 1 shows the opinions of respondents regarding progression of new policies on trade. The Figure shows that opinion is equally divided on the progression of the new policies. New economic policies may not have direct impact on this sector. However, government officials in land customs and trade centre have opinions on progression since they are directly impacted by new policies.

\subsection{Dependence between Improvement in Trade and Development in Infrastructure}

The crux of the present study is to check whether improvement in trade is associated with development in infrastructure. There are many studies in economics which reveal correlation between trade and infrastructure. Some of them can be picked up in order to check their applicability in the present trade. Trade and infrastructure have mutual association which have been observed in many countries across the globe. World 
Trade Organisation in its study across its member countries shows infrastructure as one of the components which improve trade (Nordas, et al, 2004).

Figure 1: Opinion of Respondents on Progression of Trade

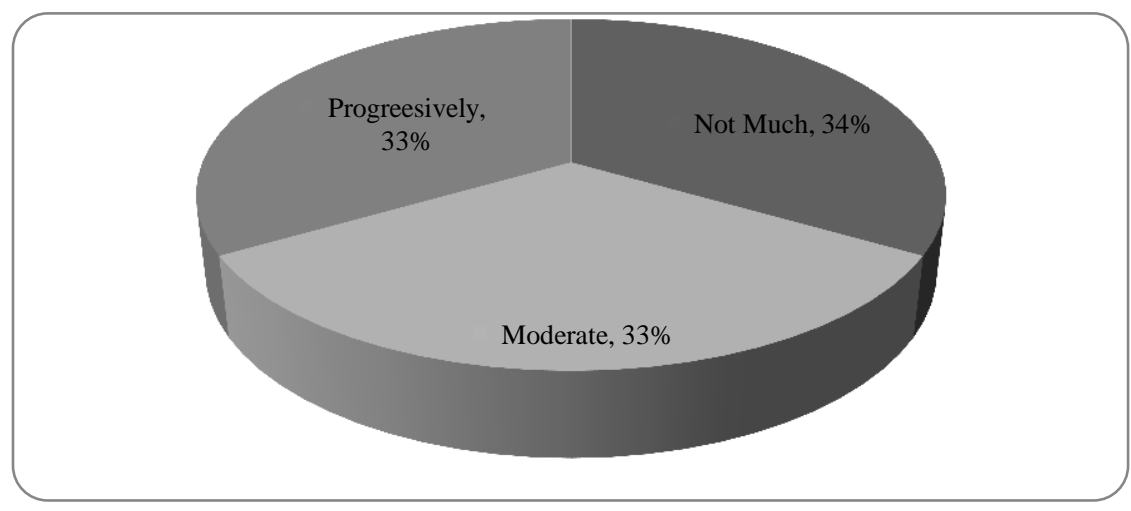

Source: Respondents at Moreh

World Trade Report (2004) also shows that key infrastructure and infrastructural services support trade. It also shows how cost of infrastructure and its quality impact on trade. The study is based on empirical studies across the globe. Infrastructure includes transport infrastructures (such as roads, railways, airports, seaport etc.) and the services given by transport, and logistic sector, and telecommunication networks. These are the sectors categorised under physical infrastructure that are characteristically crucial for moving goods and services from exporting country to importing country. Similarly financial services are also one the important service sectors which support trade. Such development in infrastructural services increases efficiency of complementary sectors in trade.

Khachatryan, et al. (2011) in their work, find out the relation between U.S. transport infrastructure improvements and international trade. Their work shows that U.S. transport infrastructure increased by 69 percent in the last decade. As a result, there had been growth in the export and import in agriculture products by 69 and 103 percent. In addition to this, their work projects the volume of containerized cargo to increase double times as they have that time. So better infrastructure and efficient transport system acts as platform to increase the level of trade.

\subsection{Infrastructural development at Moreh}

The developments in Moreh can be considered as an important aspect for Manipur and India as well. Some of the recent developments can be seen discussed as, 
the change and development in the road and transport sector in Moreh. In the past the condition of the road and transport system was quite bad. It consumes more time and energy for the travellers and businessman. The transportation of goods from Moreh to Imphal takes less time in present situation. The medical facilities in Moreh town are also improving. The Moreh sub divisional hospital is working for the betterment of the local people and Myanmarese. The number of patients coming from the nearby Myanmar region is increasing. There is also news for constructing a new hospital under the Shija Hospitals and Research centre (a renowned private hospital in Manipur).The security system is a biggest concern in Moreh town because it lies in the extreme corner of India and favourable for various insurgents groups and unlawful activities. However this system has been improved a lot because of the strict monitoring by the security in this border area. The rate of smuggling of drugs and narcotics has been reduce a lot. To control such activities there is special force deployed in Moreh call the Customs Preventive Force, frequent checking is done in the border area and Moreh town. There is less report of smuggling Heroine, precious stone etc. Under the commerce and Industries department of Manipur there is a plan of making Moreh into an international township. The negotiations are going on for acquiring a three thousand acre of Land in Moreh. The construction of Integrated Check post is going on; once the said post is complete there will be huge advantage in the field of trade, transportation, tourism, immigration, travelling, postal services, law and order etc.

\subsection{Empirical Study on the Dependence between Developments in Infrastructure and Trade}

The present study tries to find how infrastructural development at Moreh is associated with improvement in trade. According to information collected from 36 respondents, 89 percent of them respond there is positive correlation; 5 percent responds improvement in trade without infrastructure; 3 percent of them say infrastructural development without trade; and another 3 percent respond no correlation. These are shown in Figure 2.

In order to test statistically, non-parametric test called "Chi-Square Test" is performed. Chi-square is a statistical test commonly used to compare observed data with data we would expect to obtain according to a specific hypothesis. It needs "goodness to fit" between the observed and expected (differences between observed and expected). The chi-square test is always testing what statisticians call the null hypothesis, which states that attributes are independent with each other. In other words we can interpret that there is no significant difference between the expected and observed result. 
94 | FOCUS: Journal of International Business, Volume 3, Issue 1

Figure 2: Dependence between Trade and Infrastructure

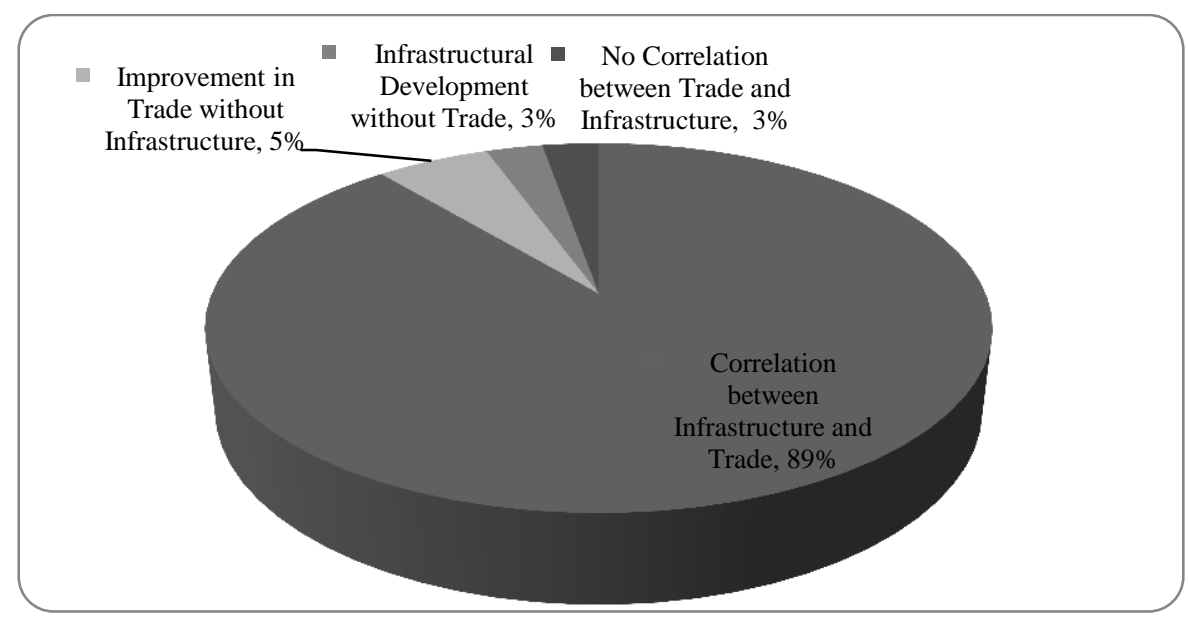

Source: Reports from Respondents

The formula for calculating chi-square $\left(\chi^{2}\right)$ and is written as $\chi^{2}=(o-e)^{2} / e$

That is, chi-square is the sum of the squared difference between observed $(o)$ and the expected $(e)$, divided by the expected data in all possible categories.

In the present study, we set null hypothesis as following:

$\mathrm{H}_{0}$ : Infrastructure and Trade are independent with each other

$\mathrm{H}_{1}$ : They are dependent with each other

Tables 1 and 2 show observed and expected frequencies of attributes, respectively.

Table 1: Observed Frequencies of Attributes

\begin{tabular}{|l|l|l|l|}
\hline Observed Frequencies & $\begin{array}{l}\text { With development } \\
\text { of infrastructure }\end{array}$ & $\begin{array}{l}\text { Without development of } \\
\text { infrastructure }\end{array}$ & Total \\
\hline Improvement in trade & 32 & 2 & 34 \\
\hline No improvement in trade & 1 & 1 & $\mathbf{2}$ \\
\hline Total & $\mathbf{3 3}$ & $\mathbf{3}$ & $\mathbf{3 6}$ I \\
\hline
\end{tabular}

Source: Author's own calculation based on information from respondents

Table 2: Expected Frequencies of Attributes

\begin{tabular}{|l|l|l|}
\hline Expected attributes & $\begin{array}{l}\text { With development of } \\
\text { infrastructure }\end{array}$ & $\begin{array}{l}\text { Without development of } \\
\text { infrastructure }\end{array}$ \\
\hline Improvement of trade & 31.16 & 2.8 \\
\hline No improvement in trade & 1.8 & 0.16 \\
\hline
\end{tabular}


Chi-squared value is found out using the formula given above and we find the calculated Chi-squared value is 5.01 which is greater than table value i.e. 3.84 at 5 percent level of significance with $(2-1) *(2-1)=1$ d.f (degrees of freedom). Hence we reject the null hypothesis i.e. improvements in infrastructure and development in trade are dependent on each other.

\subsection{Impediments in Trade and Development}

According to respondents, there are many impediments to this trade and development. All these impediments are characteristically infrastructural and institutional. Of the total respondents, 67 percent opined that there is no impediment to trade and development. However, 33 percent of total respondents have opinions that there are infrastructural and institutional impediments. The following are details on what those impediments are and how they impede developments.

\subsection{Infrastructural impediments}

Infrastructure is one of the most interesting factors for impeding development in trade. The details of infrastructural impediments are given below.

Transport Infrastructure: There is only one highway which linking Moreh, the border point, and the rest of the state. So, many traders have to rely on this highway and state and central government have no intention to construct other roads. The condition of road is also pathetic despite the status of national highway. The highway is single lane and so the breadth of the highway is not enough for two oppositely moving four wheelers at the same time. Not only is the breadth of the road, repairing the deplorable road timey not done properly. The thickness of asphalt on this road is so thin that it would be vulnerable to heavily loaded trucks.

Telecommunication: Telecommunication system at Moreh before the revolution of mobile phones was pathetic. Information on commodity price and related shipments were completely asymmetric due to lack of telecommunication systems. At present system of telecommunication as of now is better since the revolution of mobile phone. However, availability of mobile network on mountainous route is dubious one.

Power Supply: Power supply is very much important in the modern version of development especially in successful trade. Without power supply there will be no possibility for telecommunication, running hotels or lodges.

Lack of Patrolling: The whole route from Moreh to the rest of places is vulnerable to armed militants which are trespassing the whole area. There are reports that distortions and extortions are very often due to intervention of such armed persons. Non-residential 
traders are poor ones and they do not have enough capital to cover up the loss due to extortion. They are forced to pay informal taxes levied on them.

Multiple Check points: In the name of checking unofficial commodities, both central and state governments install many check points. One of the disadvantages due to such multiple checking systems is that traders have to show their commodities to customs official again and again whenever in need. It discourages traders and in order to avoid of such official harassment they bribe not to check repeatedly. Such bribing reduces profit margin of these poor traders. It is very necessary to install integrated check point with modern equipment.

\subsection{Impediments due to institutions}

These impediments arise due to types of institutions prevailing: some of the important institutional impediments and how they affect trade are given below.

Multiple Ethnicities: There are multiple ethnic communities in Manipur and most of the traders belong to major communities. The area where border trade takes place belongs to minority ethnic group who could not get much benefit from this trade. They have alienated feelings on this trade and have phobia that one day they might be displaced out of their native places. These are myopic feeling and being instigated by ethnic leaders. However, they also enjoy with better income due opening of tourist lodges and public houses. Their myopic thinking is degrading day by day since in the course of time they themselves also take part in this trade. Infrastructural handicap they faced once upon a time has been slowly removed.

Insurgency Problems: Entire North East India has many insurgency groups which oppose any kind of developments in the region. In Manipur also there are many insurgency groups who kept hiding in mountainous places. The highway passes through such mountainous places and there is no enough security patrolling on this national highway. Moreover, these groups levy unofficial taxes on traders and untimed payment is risk for their lives.

Frequent Bandh, Blockade and Strike: North East India not only popular for insurgency but also for blockade and strike. Any discontent on the role and policy of government will turn into blockade of these highways. Many people in this region use highways as weapon to express their discontent. This is due to way of survival which is local based and integration of local economy with rest of the world still remains weak.

\subsection{Conclusion}

The above study reveals the difficulties in bringing about infrastructural development in landlocked NER. However, the new Look East policy of India has made 
it possible to augment border trade, which is facilitated by infrastructural development. The same has been proven empirically. Despite the development in many sectors, infrastructural and institutional impediments, however, still exist and more needs to be done on this front.

\section{References}

Khachatryan, H \& Casavant, K., (2011). The Relationship between U.S. Transport Infrastructure Improvement and International Trade. Washington State University, Washington.

Mongelli, F. P (2005). What is European Economic and Monetary Union (EMU) telling us about the Optimum Currency Area properties? Journal of Common Market Studies, 43: 607-35.

Nordas, K. H. \& Jansen, M., (2004). Institutions, Trade Policies and Trade Flows. Staff Working Paper, World Trade Organisation, 2004-02.

Singh, M. L., \& Bosumatari, B., (2012), Trade Induced Employment Function and Multiplier. I.J.R.C.E.M., 2(11).

Singh, M. L, (2012). Dumping Potential and Intensity: A Case Study of Indo-Myanmar Border Trade. International Journal of South Asian Study. 5(2).

Singh, M. L., (2014). Institutional Development Leading Trade Developments: A Case Study of India-ASEAN Bilateral Trade. Foreign Trade Review. 49(2).

Singh, M. L. (2014). Developments in Indian bilateral trade with ASEAN: A case study on manufactured sectors. FOCUS: Journal of International Business, 1(1).

Singh, M. L., (2014). Market Access: A Case Study on Indian Pharmaceutical Goods in U.S. Market. FOCUS: Journal of International Business, 1(2).

World Trade Report. (2004). Exploring the Linkage between Domestic Policy Environment and International Trade. 